\title{
The First Japanese effort to colonize Taiwan and the Chinese Reaction
}

\author{
By Nikolaos Mavropoulos*
}

\begin{abstract}
Successful modernization at home, the self-congratulatory ideology of State Shintō and the trend of the time made Japan's expansion appear as an act of benevolence towards its adjacent, more underdeveloped nations. Before expanding abroad however the new leadership had to solidify its rule and authority in the Japanese archipelago. Initially the main Japanese islands were brought under submission and were ruled almost despotically by the Satcho leaders that came to dominate the government after their victory over the old regime. Clans were relocated or brushed aside, people were taught the standard national language and made into loyal subjects and the entire nation suddenly acquired after centuries of division a common identity (internal colonialism). Japan rapidly embraced the colonial theories and imperialistic reasoning of the West. Strategic considerations about the safety of the nation spurred Tōkyo towards controlling, absorbing or reforming the Chinese held island of Taiwan. A relatively unknown military as well as a diplomatic clash with China took place in the 1870s for the control of his island.
\end{abstract}

\section{Literature Review}

Until the 1990s those few interested in Japan's rule over Taiwan were faced with several obstacles due to the Cold War era's politics and Taiwan's delicate situation; it was only then that the official documents of the Japanese administration in the island were finally made accessible to the public. The liquidation of the Japanese empire was not a voluntary act; it was a result of Tōkyō's military defeat in the Second World War. As a consequence, it was not an issue of great political controversy domestically. In addition this nation did not have a period of gradual decolonization as was the case for Britain or France. There had been those like Yoshino Sakuzō (1878-1933) and Yanaihara Tadao (1893-1961) who had condemned Japan's imperial yearnings, but they were few and far between. In the first half of the $20^{\text {th }}$ century, opposition to the empire was neither fashionable nor widespread. To the Japanese the end of empire was and perhaps still is virtually synonymous with the defeat in the war. As the Japanese intellectual opinion moved towards the left in the postwar period, at the same time it attacked imperialism and militarism. Socialist criticism in postwar publications targeted gunkokushugi (militarism) and teikokushugi (imperialism). Nipponshugi (belief in Nippon or ultranationalism) was also subjected to criticism. In a sense, all of Japan has grown to detest and distrust these concepts. In other words, it is not just a socialist belief anymore, but the thinking of an entire generation of Japanese. Whereas in the days of the empire, there were comparatively few voices raised in opposition, in the aftermath of the empire's dissolution there has been a whole wave of

${ }^{*} \mathrm{PhD}$ Candidate, Sapienza University of Rome, Italy. 
opposition and criticism in retrospect. To some extent this appears to be the case because Japan's empire was associated with the army more than any other institution.

\section{Introduction}

This paper aims to show that the Japanese had embarked on an expansionist policy just a few years after the establishment of their modern state in contrast to many scholars that claim that Japanese colonialism was born in 1895 (with the definite occupation of Taiwan) or even later, with the RussoJapanese war of 1905. On June 211873 the Japanese Foreign Office agent Yanagiwara Sakimitsu, during his negotiations with the Yamen (Chinese Foreign Ministry) officials in Beijing, reached the conclusion that China had no jurisdiction over the southern part of Taiwan and thus Tōkyō had the right to dispatch an expedition and punish the savage inhabitants that had murdered its subjects, some fishermen in December 1871. Asked about the status of Taiwan's populace the Chinese responded: "There are two kinds of aborigines on this island. The aborigines who have been subjugated are called jukuban (barbarians inside the Qing jurisdiction); we have set up prefectures and administered them. The other aborigines who have not yet been subjugated by us are called seiban (barbarians outside the Qing jurisdiction). They are beyond the influence of Chinese civilization (huawai) and also beyond our jurisdiction". The Japanese understood that Beijing recognized its absence of sovereignty over the aboriginal territories and that it was now up to Japan to act. The Chinese carelessly renounced their responsibility gifting in practice Tōkyō carte blanche to invade Taiwan. What happened next is a matter of contention.

Yanagiwara supposedly informed the Chinese of Tōkyō's intention to act independently to chastise the "raw barbarians" that had committed the atrocities back in December 1871 and were living beyond the Chinese borders: "The Japanese government, therefore, intends to conquer the aborigines immediately. However, our Minister (Soejima) restrained the popular call for a punitive expedition in order to promote amity between the two countries". ${ }^{1}$ However, there must have been a miscommunication because in the following year when the Yamen was actually notified of the Japanese expedition it was shocked; it affirmed that the Japanese "had spoken not of a military action...but of the dispatch of officials to the aboriginal territories of Taiwan". ${ }^{2}$ In typical fashion in May 1874 the Yamen sent a vague memorandum to Foreign Minister Terashima Munenori stating that Taiwan's "territories were remote regions of China belonging to China" but the "aborigines were beyond Chinese legal and

1. N. Mizuno, "Early Meiji Policies towards the Ryukyus and the Taiwanese Aboriginal Territories," in Modern Asian Studies, 43, no. 3 (May, 2009): 714-715.

2. N. Mizuno, "Qing China's Reaction to the 1874 Japanese Expedition to the Taiwanese Aboriginal Territories," in Sino-Japanese Studies, 16(2009), 103. 
administrative control". ${ }^{3}$ The two sides also used different meanings of sovereignty, one deriving from Chinese practice and the other from European. For Beijing the absence of effective governability did not mean the loss of sovereignty over a territory. In contrast and in accordance with modern international law Tōkyō perceived Beijing's declared lack of factual authority as evidence of these territories' vacancy: aboriginal lands were res nullius and thus a punitive expedition legitimate. ${ }^{4}$

Soejima was eagerly convinced on these points by conferring with the US Minister DeLong and the Foreign Ministry adviser LeGendre. During a meeting with the former on 24 October 1872 the Japanese Foreign Minister was told that Taiwan was "floating, and would become the possession of the first to take it"; ${ }^{5}$ since Qing rule in Taiwan was nominal despite the Chinese claims, the island could be annexed by anyone willing to undertake the arduous task of civilizing it. DeLong emphasized the strategic position and natural resources of the island. He further reassured the Japanese Foreign Minister that the US government would not oppose the prospective change in ownership: "U.S. did not occupy foreign lands, it was quite happy to see states friendly to [the U.S.] occupy others' lands and develop them". Soejima's fervor for expansion ignited. By these actions the US Minister was planning to bring Japan closer to the US and the Western powers. He genuinely feared a joint Sino-Japanese action against the West. ${ }^{6}$ In the following days Soejima, through DeLong's mediation met with "Formosa expert" LeGendre and became even more confident over the dispatch of an armed mission overseas. On October 25 the former Amoy consul confirmed that the Chinese had already admitted that parts of Taiwan lay beyond their control. ${ }^{7}$ Two days later he encouraged Soejima to send 2,000 men claiming that this force would be sufficient to subdue the aborigines. Once there the garrison could not be easily removed. The latter boastfully responded that he could gather 10,000 with no effort; regardless of the domestic problems there were 400,000 "brave" but discontent ex-samurai willing to prove their martial valor. LeGendre in addition supplied

3. Although the Qing government asserted that Taiwan was administrated normally as a district of the Fukien province it failed to incorporate the mountainous eastern and south-western areas into the administrative units of the prefecture. See G. Fox, Britain and Japan, 1858-1883 (London, 1969), 281.

4. Mizuno, "Qing China’s Reaction", 104.

5. H. Uemura, "The colonial annexation of Okinawa and the logic of international law: the formation of an 'indigenous people' in East Asia," in Japanese Studies, 23 no. 2 (September 2003): 110.

6. S. Caruthers, Charles LeGendre, American Diplomacy, and Expansionism in Meiji Japan, 1868-1893, Ph.D Diss., University of Colorado 1966, 59-61.

7. As part of his investigation of the March 1867 massacre of American sailors by the aborigines (Rover incident) LeGendre demanded that the Qing authorities punish the culprits and to exercise formal jurisdiction in line with international law. Otherwise he warned that the southern territories could end up as targets of western imperial designs. Chinese authorities considering the great price in money, effort and lives that the proposal entailed, remained unmoved. They responded to LeGendre's overtures by insisting that Beijing held sovereignty over the entire island but the aboriginal territory to the south lay outside of China's legal jurisdiction and administration. See R. Eskildsen, "Of Civilization and Savages: The Mimetic Imperialism of Japan's 1874 Expedition to Taiwan," in The American Historical Review 107, no. 2 (April 2002), 395. 
maps, recommended the hiring of American advisors and provided detailed diplomatic and military strategy suggestions. ${ }^{8}$ Peshine Smith, an American legal adviser to the Foreign Ministry, also suggested that Japan was compelled to acquire the islands if China was unable or unwilling to effectively rule the southern Taiwan tribes. LeGendre in his memoranda to Soejima illustrated that bringing civilization to the barbarians was a sufficient reason to justify the colonization of a territory according to western standards. In his memoranda spanning from November 1872 to mid-March 1874 he persistently suggested the occupation not only of the aboriginal territory but of the island's entirety and even Korea to secure Japan's strategic position against the powers' imperialistic schemes. He argued that since the indigenous Taiwan was backward it was likely that Westerners would employ the terra nullius principle as an excuse to occupy the island. Tōkyō had to obtain Taiwan either by enticing Beijing or by forcibly occupying it "in order to uphold its prestige in the East". 9 Furthermore, for him the Chinese claims were superficial and unfounded from the international law's point of view. ${ }^{10}$ LeGendre's final memo, on 13 March 1874 to Councilor of State Ōkuma, argued that Japan had to punish and "civilize the whole aboriginal population" but its "real object will be the annexation of aboriginal Formosa". ${ }^{11}$ Soejima was delighted. ${ }^{12}$ Two days after Yanagiwara concluded negotiations on June 21, 1873, Grand Councillor Saigō Takamori dispatched agents to survey Taiwan and Southern China. He also appointed Major Fukushima Tadashige (Reisuke) as Japan's consul in Amoy. ${ }^{13}$ Imperial Councilor Itagaki and General Saigō Tsugumichi (18431902), the younger brother of Takamori, also endorsed a military expedition. Furthermore, on 8 March 1873 sailors from the Oda prefecture, in Japan proper, were once again mistreated by the aborigines. Saigo in a letter dated August 31873 informed Prime Minister Sanjō Sanetomi that domestic discontent was pilling up and the Imperial Guard was adamantly asking for

8. W. C. McWilliams, "East Meets East. The Soejima Mission to China, 1873," in Monumenta Nipponica, 30, no. 3 (Autumn, 1975): 242-3.

9. L. Gordon, "Japan's Abortive Colonial Venture in Taiwan, 1874," in The Journal of Modern History, 37 no. 2 (Jun., 1965), 172.

10. Contrary to these claims LeGendre stated in June 1867 while exploring Taiwan:"If the native territory is not Chinese in population, it is Chinese in fact ... having a sort of preemption claim on it". See Caruthers, Charles LeGendre, 39.

11. LeGendre explained: When this has been done, and after the Bontans have been reduced or have submitted, Japan will declare that, as the pacification of the island depends upon its being occupied by a civilized power, since it had been found vacant and the Japanese forces are there, there they shall remain; and that, for the benefit of the whole civilized world the aboriginal portion of Formosa is declared to be annexed to the Empire of Japan. See Ibid., 139.

12. Mizuno, "Early Meiji Policies," 707.

13. It was probably in early December 1873 when Fukushima submitted his report for a Taiwan expedition to Iwakura pointing out the absence of Qing authority in South Taiwan. On December 17 Ōkubo Toshimichi received the reports of the agents that surveyed Taiwan in line with Saigo’s orders. Ibid., 722. 
swift action against Taiwan. ${ }^{14}$ The aggressive tendencies that had not found an outlet in Korea had to be directed elsewhere (just 5 years after the unification the government was split over the debate about Korea's possible invasion, the nation's closest neighbor). Furthermore after years of civil war and numerous samurai and peasant domestic uprisings a far away adventure was preferable than another domestic one. On November 111873 a warship was sent to Taiwanese waters and at around the same time 8 army officers departed for China to collect intelligence disguised as students. ${ }^{15}$ The overseas campaign would yield only benefits for the Meiji government. It would reassert Japan's position in Asia, test the reorganized Meiji armed forces, calm the internal tensions, acquire recognition by the foreign powers, and secure the country's southern borders. If Tōkyō managed to annex the island would obtain its entrance in the group of the imperial powers discarding once and for all the title of the backward, endangered, semi-colonized nation as early as 1874. Even if that was not the case, a western-style punitive expedition against savages that often threatened the navigation in the Far East could gain the sympathy of the powers and define the Japanese as civilized in contrast to the barbarous aborigines. $^{16}$

14. The historian Edwin Pak-Wah Leung suggests that Ryūkyūan crews were mistreated by the aborigines numerous times in the past; Tōkyō decided to redress the 1871 incident to satisfy the agitated expansionist elements in Japan. These disappointed by the lack of action against Korea rallied around Etō Shimpei who had launched a massive anti-government rebellion in February 1874 in Saga. See E. Pak-Wah Leung, "The Quasi-War in East Asia: Japan's Expedition to Taiwan and the Ryūkyū Controversy," in Modern Asian Studies, 17, no. 2 (1983): 262-265.

15. Mizuno, "Early Meiji Policies," 718-722.

16. The Japanese press throughout this period highlighted the nation's civilization mission and challenged the western view of the country as semi-civilized. The pressure exerted by the foreign powers on Japan could be displaced onto the aborigines. To emphasize Japan's progress and cultural superiority in Asia the press described the enemy, the aborigines as cruel, flesh eating barbarians. Newspapers often exaggerated the aborigines' ferocious and inhuman nature. The 16th April 1874 edition of the Yübin hōchi shinbun portrayed them as "wild and rapacious, have large bodies and are very strong." Some journalists perpetuated the image of the native Taiwanese as cannibals. Japan Daily Herald published on May 25 that they live "by eating the meat of the people they defeat in battle". Journalist Okada Jisuke, in his May 1874 reports exalted Japanese martial valor in contrast to the cunning barbarians who "do not know ethics". The pictorials depicted the Japanese in a progressive light, robust, modern, dressed in Western attire in contrast to the wretched savages in order to signify the cultural abyss that separated them. The Tokyo Nichi Nichi shimbun published on April 161874 read: "...Our proud regiments and stately armies are now headed toward that lone island. In a matter of ten days, the Rising Sun flag shall shine its light in the four directions, and with that, the righteousness of our nation shall be known to all. Surely this cannot fail to be a moment when our hearts as humble subjects will dance with emotion! And at that time, we shall succeed in shaming the Westerners". See Eskildsen, "Of Civilization and Savages", pp. 339-406; and Matthew Fraleigh "Japan's First War Reporter: Kishida Ginkō and the Taiwan Expedition," in Japanese Studies, 30, no. 1, (May 2010): 53. 


\section{Organizing the First Overseas Campaign}

Finance Minister Inoue and his Deputy Shibusawa Eiichi, (1840-1931) expressed their disagreement to the proposed expedition on November 26, 1872. Reforms at home and maintenance of peaceful relations with China had to be Japan's priorities as Inoue affirmed on December 18. Kido Takayoshi, Minister of Education and Grand Councilor and Itō Hirobumi, the Minister of Civil Engineering and also a Grand Councilor, both members of the Iwakura mission in Europe at the time, were also against it. Military unpreparedness as Yamagata put it was the main but not the only obstacle. Due to the fiscal difficulties and the instability of the new regime the government at the time chose to dispatch an envoy to negotiate with Beijing. ${ }^{17}$ Soejima before obtaining his appointment claimed: "No one except me is able to prevent foreign powers aiming at Taiwan from impeding our imperial undertaking, to convince Qing China to cede the aboriginal territories to us, to bring the land under civilization, and to gain the confidence of the inhabitants. I entreat your Imperial Majesty to send me to China to ratify the treaty, and to proceed to Beijing to convince foreign delegations not to question the treaty with China, to confer with the Qing government on the Audience Question, and to give prior notice to the government of a punitive expedition to Taiwan. And, with the expedition, we should clarify the demarcation of Taiwan and develop half of the island". To the agitated troops anxious to attack the unruly tribes, namely the Botans or Boutans that had murdered imperial subjects he announced that: "they would be called upon to occupy aboriginal territory, to colonize it, and to consolidate that area as the southern gate of the Japanese Empire". On February 17, he disclosed to Ōkuma: "I am fairly confident of obtaining half of the island through negotiations. Resort to arms may be unnecessary even if the entire island is desired. I believe that this opportunity must not be missed in order to obtain half of the island now and to acquire the entire land through negotiations in four or five years". ${ }^{18}$

Thus, the expedition would not solely be a righteous enterprise to demonstrate Japan's determination to protect its people to the civilized nations of the world. Nor a mere act to elevate its prestige. ${ }^{19}$ Under the initial direction of Soejima and after his resignation in October 1873, of Ōkuma Shigenobu, the new Finance Minister, the savages' chastisement evolved into an organized plan for the seizure of the entire island. According to a Foreign Ministry official, Soejima was concerned about the rumor that Berlin, among other suitors, was interested in Taiwan and desired to act first and seize it on Tōkyō's behalf. On the other hand, Inoue Kaoru while in favour of annexing foreign territory disapproved the expenditure that such an expedition would demand.

17. Mizuno, "Early Meiji Policies," 709

18. Ibid., 711.

19. Ōyama Tsunayoshi vice-governor of Kagoshima declared upon hearing the news of the massacre on 31 August 1872: "I, Tsunayoshi, plead with the government to launch a punitive expedition to chastise the aborigines for the sake of imperial prestige. I would therefore like to be authorized to borrow battleships and annihilate the ringleaders and then enhance imperial prestige overseas and console the anger of the victimized islanders. I beg the government to grant my requests", see Ibid., 701. 
He stressed on November 18, 1872 that Taiwan is a strategically important island, desired by the Great Powers and therefore, Beijing amidst great difficulties could be persuaded to surrender it to Japan. The Japanese Government (Daijōkan) and in particular Sanjō on March 9, 1873, before the departure of Soejima's mission to Beijing alarmed by his overtures dismissed LeGendre's propositions and gave specific instructions to the Japanese ambassador to avoid friction with the Qing government. Upon Soejima's return in Tōkyō on 25 July 1873, regardless of the mission's presumed success, the government's priority was the debate about Korea, the political crisis that was dividing the nation. It was only after the official settlement of the Korean issue in October 1873 and Soejima's resignation that Sanjō instructed Ōkubo, the Home Minister, and Ōkuma to investigate into the Taiwan incident in early January 1874. On January 29 and while tensions were still high, Ōkuma in turn assigned to Yanagiwara and his colleague Tei Nagayasu to submit a report on the matter. On February 6 they presented "The outline of the disposition of the Taiwanese aboriginal territories". The Cabinet on the same day approved their proposal and granted 500,000 yen for the dispatch of an expedition. ${ }^{20}$

In the draft the capture of South Taiwan was presented as the Japanese government's duty confirming Japan's early disposition to expand overseas. Furthermore, Japanese consuls should be dispatched to Taiwan "to undertake public education by telling the Chinese in these places the sincere desire of Japan to open up the aboriginal territory and civilize the tribes". ${ }^{21}$ Iwakura after hearing the content of the recommendation exclaimed "I hope a plan will be adopted to make it our dependency". ${ }^{22}$ In his 28 March correspondence with Ōkubo the former disclosed that Saigo had proposed to him the seizure of the aboriginal territories. However, the Cabinet did not include such a directive in its subsequent guidelines. ${ }^{23}$ If an annexation plan was to be implemented it was highly classified, known only among the main directors of the operation. The pretext for action was the massacre of the Japanese sailors. Subduing the barbarians was an action to avert further attacks on Japanese subjects in the future. Inclined to maintain friendly relations with China, Tōkyō decided to dispatch another ambassador to Beijing to negotiate and reassure the Chinese that the imminent conflict in South Taiwan did not signify hostility. On 8 April Yanagiwara Sakimitsu was named Minister plenipotentiary to Beijing while the imperial edict of 4 April 1874 appointed Saigō Tsugumichi as "Commander in Chief in Charge of the Barbarian Part of Taiwan". Admiral Akamatsu Noriyoshi (1841-1920) and Major General Tani Kanjō or Tateki (1837-1911), ${ }^{24}$

20. Ibid., 723-724.

21. S. Suzuki, Civilization and Empire: China and Japan's Encounter with European International Society (New York, 2009), 152.

22. Gordon, "Japan's Abortive Colonial Venture," 175.

23. Mizuno, "Early Meiji Policies", 725-726.

24. General Tani envisioned the seizure not only of the aboriginal part but of the Qing possessions in the North as well. In the future Japan could use the island as a base for hostile operations against China, sending "robbers to instigate rebellions" and taking advantage of the chaos to obtain parts of the country. That was the predisposition of Tani, one of the most important members of the mission. See D. Orbach, "'By not stopping': The first Taiwan 
were appointed as his second in command. ${ }^{25}$ Six ships, three transport and three gun vessels were chartered for the mission. Saigo intended to annex the island and distribute plots of Taiwanese land to his men convinced that the castigation of the natives would not provide sufficient satisfaction to the zealous exsamurai from Satsuma. His troops were named "colonizing soldiers" (shokuminhei). A concurrent edict addressed to him read: "the purpose is to induce the aborigines to become civilized gradually after subduing them and finally promote salutary enterprises between them and the Japanese government". These stationing military colonists would be installed in small branch camps that would form the basis of permanent settlements along the Taiwanese coast. ${ }^{26} 300$ women and even children were said to have followed the soldiers as many of them believed that they would be permanently settled in the island. Saigō's associate Kodama Toshikuni who was dispatched to gather intelligence in Taiwan, advocated the reclamation of land for agriculture and the permanent settlement in the island. By early March Saigō had undertaken full scale military and colonization preparations in secrecy in order not to provoke protests by the foreign envoys. Ōkuma began to acquire planting seeds for cultivation in Taiwan. ${ }^{27}$ According to some sources $2 / 3$ of the amassed forces were made up by laborers, men able to establish a military colony by constructing barracks, encampments, wells, roads and bridges. ${ }^{28}$ LeGendre was appointed military advisor to the expedition and was promised the title of the governor if Japan acquired Taiwan permanently. ${ }^{29}$ Finally Ōkuma was named Director of the Bureau of Aboriginal Affairs on Taiwan with headquarters at Nagasaki subordinated to the Cabinet. ${ }^{30}$ Saigo in line with the decree of the $6^{\text {th }}$ of February was ordered to limit and concentrate his action on the military campaign and leave diplomacy to the government. In case of Chinese of Western protests he had to appeal to "the imperial throne for orders". ${ }^{31}$ The expedition was to be accompanied by two American advisers: Lieutenant Commander Douglas Cassel (1846-1875) with the task of finding suitable places for the establishment of colonies in the eastern coast of Taiwan and Lieutenant James R. Wasson who had been appointed the director in charge of the necessary field works. ${ }^{32}$

On the 2nd and 13th of April the British Minister in Japan Sir Harry Parkes enquired Foreign Minister Terashima Munenori if Tōkyō had obtained Beijing's permission for the proposed campaign. If the Qing government considered the Japanese action hostile and war broke out Britain had to prohibit

expedition (1874) and the Roots of Japanese Military Disobedience," in The Journal of Japanese Studies, 42, no.1, (Winter 2016): 49-50.

25. Ibid., 39.

26. Eskildsen, "Of Civilization and Savages", 397.

27. Orbach, "By not stopping", 38.

28. Gordon, "Japan's Abortive Colonial Venture", 175.

29. Caruthers, Charles LeGendre, 62

30. Mizuno, "Early Meiji Policies", 726-727.

31. Orbach, "By not stopping", 40.

32. Gordon, "Japan's Abortive Colonial Venture", 176. 
the employment of British citizens and ships in the conflict.$^{33}$ At the same time he telegraphed to vice Admiral Charles Shadwell (1814-1886) at Hong Kong to keep him abreast of the developments. Shadwell dispatched the warship Hornet to inspect the island's ports for the time being; more British vessels would menacingly follow in the area unless Tōkyō showed restraint. ${ }^{34}$ In addition fearful of a protracted conflict that would endanger British commercial interests in Taiwan ${ }^{35}$ and the Far East in general Parkes convinced the Spanish and Russian Ministers to declare their neutrality in the event of an upcoming war. On 9 April Parkes questioned Terashima as to the purpose of the endeavor and the location of the Meiji troops' landing. The next day the Japanese Foreign Minister replied that that the expedition's aim was not to wage war on China but to make Taiwan's coasts safe for every nation's sailors and castaways. ${ }^{36} \mathrm{He}$ also cited similar retributive actions taken by the powers in the past. ${ }^{37}$ Under Parkes' influence the Japan Daily Herald edition of 17th April criticized the American advisers' association with an unjustified attack upon Chinese territory. As a result John Armor Bingham, the new Minister after DeLong's departure in September 1873, stated on 19 April that involvement of American vessels and personnel to a campaign against China would be a violation of the 1858 Sino-US treaty and international law. The US Minister demanded to see Beijing's written consent to the expedition. Bingham partially to avoid the infringement of the Sino-American relations ordered the exclusion of the Americans and of the transport ship New York from the campaign. ${ }^{38}$ The German Minister Max von Brandt also warned that the expedition would result in failure and confided to the other foreign envoys that a bloody war between Japan and China was very probable. Ōkubo and the rest of the Council of State did not expect such a reaction and shocked by Westerners' immediate change of heart decided to postpone the campaign on 19 April 1874. The Americans in

33. The British ship Yorkshire was contracted by the Meiji government to take part in the campaign besides the Japanese Nisshin and Takeharu. The Yorkshire at the end was ruled out whereas two British assistants, named P. Manson and Patterson annulled their contracts after Parkes' protests. See Caruthers, Charles LeGendre, 138.

34. L. Gordon, "The Cession of Taiwan: A Second Look," in Pacific Historical Review, 45, no. 4 (Nov., 1976): 551.

35. The ports of Taiwan were opened to foreign trade since the 1860s. In 1873 the exports and imports of Tainan-Takow (Kaohsiung) ports amounted to 602.826 pounds and those of Keelung and Tamsui to 473.964. Britain held the lion's share of this trade but German merchants had started making headway in the 1870s. Robert Swinhoe (1836-1877) the British consul at Tainan in 1861 proposed to his government the seizure of the island's east part as a penal colony. See Fox, Britain and Japan, 284.

36. Orbach, "By not stopping", 41.

37. Adoption of Western civilization went hand in hand with adoption of Western imperialistic practices. In other words colonialism was not the result but a prerequisite in the path to modernization and a means of finally resisting the Western encroachment. See Eskildsen, "Of Civilization and Savages", 391-392.

38. On 24 April 1874 Ōkuma ordered the American experts to remain in Japan. Cassel and Wasson had already left for Taiwan but the New York, still anchored at Nagasaki, was detained. On 4 May Saigō agreed to send back the two advisors but he never did. See Gordon, "Japan's Abortive Colonial Venture", 176-177. 
particular had chiefly encouraged and formulated the Taiwan policy ${ }^{39}$ and had convinced the Japanese of the legitimacy of their undertaking. Besides, preventing the savages from endangering lives and trade in the Far East served a greater humanitarian purpose. Meiji leaders believed that Western governments would look favorably on any action aiming to improve conditions in Formosa. ${ }^{40}$ When Parkes learned from Soejima on 7 August 1873 the Japanese intention to attack the aborigines he did not express any objection. That was also the case with the Ministers Thomas Francis Wade of Britain and Frederick F. Low ${ }^{41}$ of the United States in Beijing. ${ }^{42}$ However Wade, brought up to speed by Parkes, informed the Zongli Yamen on 18 April of Tōkyō's intentions and instructed the British merchants and consuls in China to refrain from any kind of cooperation with the Japanese against China. The stunned Chinese responded that they had complete ignorance of Japanese plans ${ }^{43}$ and they had not granted their permission. Japan at the time of the Saga rebellion (February-April 1874) appeared to them politically and economically unable to undertake an overseas campaign. Finally they claimed jurisdiction over the entire island of Taiwan. Wade, conscious of the Chinese feebleness, was concerned that the expeditionary force would attempt the capture of the island with or without the consent of Beijing or even Tōkyō's for that matter. ${ }^{44}$

Saigo Tsugumichi with the imperial edict of 4 April did not feel obliged to respect the foreigners' wish or the government's frustrating and humiliating decision. Waiting in Nagasaki with his 3,658 men, including 295 Satsuma volunteers he grew restless. ${ }^{45}$ A disgraceful annulment of the expedition or suspension of the operations would enrage the soldiers thirsty for adventure and glory. The Japan Daily Herald published on 18 May that soldiers were threatening to decapitate Saigo in case the enterprise was annulled. On the 27th he sent Fukushima with 270 soldiers on board of the Yūkomaru ${ }^{46}$ to Amoy in

39. Besides LeGendre, J. M. Batchelder an American merchant in China supplied intelligence on military installations in Taiwan and even proposed to Ōkuma the acquisition of three of his ships for the expedition. See J. C. Lebra, Ōkuma Shigenobu: Statesman of Meiji Japan (Canberra, 1973), 25-26.

40. S. Caruthers, "Filibustering to Formosa: General Charles LeGendre and the Japanese," in Pacific Historical Review, 40, no. 4 (Nov., 1971): 449.

41. Low did not voice his disapproval at the time. However, he preferred that Japan attacked Korea rather than Taiwan as he wrote to DeLong on 26 December 1872: "It seems to me that if the Japs are really spoiling for a fight they had better go for Corea (sic). In that case the sympathy and moral support of all the Treaty Powers could be counted on". See McWilliams, "East Meets East", 263.

42. Mizuno, "Early Meiji Policies", 727-729.

43. In contrast to Beijing's ignorance the Qing officials in Fukien, witnessing Japanese agents surveying Taiwan in late March suspected that a hostile action was probable. See Mizuno, "Qing China’s Reaction", 106.

44. Fox, Britain and Japan, 290, 298.

45. Mizuno, "Early Meiji Policies", 729.

46 In May 1874 the government bought thirteen vessels for 1,506,800 yen to replace the revoked foreign ships. The contract for the transportation of troops and supplies was awarded to the Mitsubishi steamship company due to Ōkuma's close relations with Iwasaki Yatarō (18351885) founder of the company. It was the start of a promising partnership. The government found a keen collaborator to its schemes and developed the strategically crucial maritime sector against the foreign competitors; the ships were granted to Iwasaki as well as an annual subsidy 
South China. The latter reached the city on 3 May, delivered the news of the expedition via a formal letter to the Qing Viceroy of Fujian and Zhejiang ${ }^{47}$ and started assembling supplies for the incoming troops. The Viceroy condemned and demanded the annulment of the mission 8 days later. Back in Nagasaki the secretary of the Cabinet Kanai Yukiyasu (1833-1907) arrived at the city and ordered its governor to delay the departure of the warships. To avert the international crisis Ōkubo also rushed to Nagasaki to convince Saigō to comply with the Daijōkan's new orders. He arrived there on May 3 but the second wave (4 troopships) had departed the day before. The expedition was not canceled. It was authorized on the spot but post facto. Hereafter its aims were greatly restricted under the pressure of the foreign representatives' protests. If China's reaction was stiffened the government could claim that Saigō had acted as a marauder without Tōkyō's approval in an effort to evade the international complications. On 4 May Saigō, Ōkubo and Ōkuma agreed to proceed with the punishment of the savages but to dismiss the rest of the foreign advisors and possibly abandon the colonization plan. Tōkyō's secret plan for the swift capture of the island was unexpectedly compromised by the Foreign Ministers. On 17 May 1874 Saigo left for Taiwan with the rest of his forces on board of the Takasago Maru (Takasago was the name given to Taiwan by the Japanese in the Tokugawa period) steered by the Captain A.R. Brown, a Scot, who had remained on board despite Parkes' efforts. ${ }^{48}$ Saigō landed 5 days later. On 16 May Prime Minister Sanjō approved formally the fait accompli; the government came to understand that the revocation of the nation's first military venture abroad could result in embarrassment and further discontent at home. ${ }^{49}$

of 250,000 yen after the end of the operation. In addition, it purchased the land facilities and 18 vessels of rival foreign companies, and transferred them to Mitsubishi strengthening the company and by extension the Japanese economy. In exchange it was Mitsubishi that transported the government's troops during the Satsuma Rebellion in 1887. Mitsubishi bolstered by state subsidies and operated by foreign technicians, workers and instructors, opened up the Yokohama-Shanghai (1875), Taiwan and Korea lines and forced out of competition the British "Peninsula and Oriental Steam Navigation Company" that was operating in the Far East. See K. Yamamura, "The Founding of Mitsubishi: A Case Study of Japanese Business History" in The Economic Development of Modern Japan, 1868-1945: From the Meiji Restoration to the Second World War, vol. 1, ed. S. Toliday, (Cheltenham, 2001), 350-356. Iwasaki's and Mitsubishi's participation in the 1874 expedition is considered by some a selfless, virtuous patriotic deed to this day. See M. Munsterhjelm, "Corporate Protectors of State Sovereignty: Mitsubishi's and a Taiwan Affiliate's Accounts of Relations with Taiwan Aborigines," in Asian Ethnicity, 15, no.3 (2014): 361-369.

47. The Viceroy was not thrilled about the news: "If Japanese enter the central region of Taiwan, I will demand the local authorities to defend with the troops and local militia. However, if the Japanese only seek revenge on the aborigines for killing the Ryukyu victims, we will reason with them..." see Lung-chih Chang, From Island Frontier to Imperial Colony: Qing and Japanese Sovereignty Debates and Territorial Projects in Taiwan, 1874-1906, Ph.D Diss. (Harvard University, 2003), 63.

48. Mizuno, "Early Meiji Policies", 730.

49. Orbach, "By not stopping," 45. 
On 6 May 1874 the Yūkommaru having left Amoy the previous day reached Liangkiau Bay (Hengchun) in Taiwan's southernmost tip. Upon landing ${ }^{50}$ on the morning of the $8^{\text {th }}$, the Chinese interpreter of the mission approached the friendly natives of the village called Sialiao and invited them to the Japanese campsite. They were told that they Japanese came to punish the Botan tribe, responsible for the massacre of the emperor's subjects. Many were recruited to dig trenches and build cottages for the Japanese while two of them were retained as interpreters. Employing the service of these interpreters the Japanese contacted the local tribes who, except the Botans and their allies Kusukuts, welcomed the expedition. ${ }^{51}$ The Chinese residents did not offer any opposition. Two days later Fukushima, Wasson and Cassel decided to move the camp near Sialiao. On 10 May Admiral Akamatsu and General Tani arrived at the site with 500 men and six days later supplies, especially timber for the construction of loggings, laborers and more troops reached the camp. On 17 May 100 Japanese in a reconnaissance mission two miles eastward from their camp were attacked by some natives and lost two men. Akamatsu on board of the Nisshin surveyed the southern shores until the 19th when his crew was fired upon by the aborigines. ${ }^{52}$ Akamatsu and the two American experts interviewed the chieftain of the local tribes, Yee-suk known as Isa, who suggested caution in dealing with the ferocious Botan tribe. A skirmish took place on the 17th but the decisive battle occurred on 22 May when Colonel Sakuma Samata's (18441915) men engaged the enemy. Samata already a hero of the Saga rebellion was to be a general and the fifth colonial Governor-General of Taiwan in April 1906. In the battle of Sekimon (stonegate) 30 to 50 Botans, among them their chief and his son, were killed. The Japanese lost 6 men. The victors took the heads of 12 fallen enemies according to the medieval samurai custom. ${ }^{53}$ On the same day Saigō, upon disembarking from the Takasagu Maru among 1500 soldiers and workers, ordered his soldiers not to loot, rape, or harm "innocent aborigines". ${ }^{54}$ On 21 June two Chinese warships appeared menacingly two miles off the Japanese camp. On the 23th high rank Qing envoys met with Saigo at Liangkiau to deliver the Fukien Viceroy's response to his letter presented by Fukushima 20 days earlier. The Chinese stated that the island

50. The transfer of men and supplies ashore was quite "confused" for the "official reporter" of the expedition, the American journalist House. It was fortunate that the local tribes were friendly and did not attack the unorganized landing troops on the spot. They were lacking modern equipment and the outdated logistics system did not differ substantially from what was used in the sixteenth century. See E. Howard House, The Japanese Expedition to Formosa (Tokyo, 1875), 46-53.

51. J.W. Davidson, The Island of Formosa, Past and Present: history, people, resources, and commercial prospects: tea, camphor, sugar, gold, coal, sulphur, economical plants, and other productions (London-New York, 1903), 126-127.

52. Ibid., 132.

53. Fox, Britain and Japan, 296.

54. These orders were not obeyed to the letter. Akamatsu, Tani, Cassel and Wasson repeatedly faced insubordination, violent behavior towards the Taiwanese coolies and "shameful illicit relationships with women". Wasson in particular in his report to Ōkuma lamented the soldiers unorderly attacked the enemy against orders. At the battle of Sekimon Admiral Akamatsu admitted "that the men had acted without orders". See Orbach, "By not stopping", 47-48. 
belonged to China and the invaders after the eradication of the savage pockets had to surrender the area to Beijing. They also suggested that they participated in the military operations alongside Saigō's forces. The commander politely rejected the idea, maintained that these regions were not under the control of China and declared that the future of Taiwan did not depend on him. He was just directing the campaign; the rest was in Tōkyō's hands. Similar meetings took place for the two following days. ${ }^{55}$

On 25 May Saigō conferred with Yee-suk and four minor leaders at his camp. He announced his objective to vanquish the Botans and the Kusukuts and asked for their collaboration. LeGendre had advised Saigō Tsugumichi that certain tribes could be allied against the hostile Bontan tribe, by promising them a reward in the form of the Bontans' lands. ${ }^{56}$ Yee-suk accepted but objected to the Japanese proposal to lease a piece of aboriginal land on the East coast of Taiwan. ${ }^{57}$ After the Sekimon battle the Japanese force pressed forward looking for the Botans' main settlement. It was evident that the enemy could not put up much of a fight. Tōkyō had misjudged the population, political organization and manpower of the tribes in the interior of South Taiwan. According to Yee-suk assessments the entire 18 tribes of the Liangkiau valley could amass only 2,360 men. The rival Botans and Kusukuts clans numbered 250 and 190 fighting men respectively whereas the Japanese detachment consisted of 3,500 troops. Without proper maps, locating their villages, a process which involved the crossing of steep mountainous regions with inexistent roads and swollen streams under extreme heat, was more challenging than the fight per se. ${ }^{58}$ On 2 June, Tani's group was supposed to explore the

55. House, The Japanese Expedition, 78-79.

56. Caruthers, Charles LeGendre, 162.

57. In the 15 May edition of the Tokyo Nichi Nichi shimbun the journalist Kishida Ginkō (1833-1905) justified Saigō's attempt to establish a colony: "The major purpose of this expedition is to expand the imperial domain of our nation". See Chang, From Island Frontier to Imperial Colony, 46-47. Ginkō served as war reporter to Taiwan, the first of his kind in Japan, from where he colorfully described not only the military engagements but also his aspirations. His expansionistic views were particularly popular; the newspaper during the publication of Ginkō's column "News from Taiwan" increased its sales by 50\%. On 28 April, he wrote: "Our advance into Taiwan is the first since Toyotomi Hideyoshi's attack on Korea and all of us who are accompanying the expedition must bear this fact in mind. Above all, we must be scrupulously careful not to do anything that might lead to the humiliation of our Great Japan. The beginnings of prosperity for our nation lie in this endeavor we are undertaking at present. We must ensure that affairs turn out well; then, the territory of the Japanese nation will be increasingly enlarged, frontiers opened, and trade enriched such that the honor of our imperial nation will shine to the whole world". On 15 May, he stressed: "Our government is now deploying troops and its intent is surely the following. The soldiers will first commence their operations in the land that lies to the south of the border with Chinese territory. Once they capture this land, they will make it a colony and then proceed to station troops throughout the land lying south of the Chinese border, gradually developing it. They will fell trees and burn brush, teaching and leading the native savages and thereby expanding the territory of our imperial state". On 13 June 1874 the journalist proposed yet again the colonization of the island whereas on his 28 June report he exalted the fertility of its soil. See Fraleigh "Japan's First War Reporter", 54-60.

58. The entire campaign cost 542 lives to the Japanese: 530 from illnesses and 12 as a result of the fighting. See K.-H. Kim, The Last Phase of the East Asian World Order: Korea, Japan, and the Chinese Empire, 1860-1882 (London, 1980), 196. 
interior but lost its way and small squads set out to find it. Saigō divided his force in three columns and set the 1st of June as the date for the commencement of operations in the interior. ${ }^{59}$ When the main force marched against the Botans' base it discovered the graves of the Ryūkyūans murdered there in $1871 .^{60}$ After a day traversing the jungle and overcoming obstacles set up by the enemy, they approached their objective; after some sporadic enemy fire tha tresulted in a few casualties the village was evacuated by its inhabitants that fled to the mountains. The settlement was burned to the ground by the invading force. Akamatsu's force en route to Kusukut suffered the losses of 3 men while 2 more were wounded but eventually occupied the village and torched it. Guards were set to patrol the deserted villages and the jungle paths and burn any villages that were associated with the enemy tribes. The main force retreated to Sialiao. On 4 June Saigo declared that the aborigines were subjugated. ${ }^{61}$

In the evening following the Sekimon battle the leader of the Hongkang village rushed to the Japanese headquarters to request Tōkyō's official protection. ${ }^{62}$ The annihilation of the fierce Botan tribe compelled the aborigines to submit to the conquerors. On June 9 a conference was held with the friendly tribes and the leaders of the conquered local villages. The aborigines received Japanese flags to hang at the entrance of their settlements as protection from their enemies; it was a sign of allegiance. ${ }^{63}$ They also received gifts and money. The Japanese side requested and obtained in return the right to temporarily establish ports on Taiwan's east coast. On 11 June Akamatsu and Fukushima landed with 50 men at Kenting the site of the Rover Incident and distributed flags to the local chiefs. By the end of July South Taiwan's tribes had surrendered to the Japanese. However the foreign objections, ${ }^{64}$ the island's unsanitary environment and the diseases that decimated the occupying force denoted that the plan to settle former Satsuma samurai on the island had to be abandoned. Saigo was himself suffering from the boredom and the tropical diseases due to the bad water and food was searching for a honorable excuse to leave after the end of the hostilities. Tani, noticing that as time passed the men's

59. The first column led by Tani headed towards Hongkang in the North with 500 men. The second, comprised by 300 soldiers, set course for Sekimon under Saigō. Akamatsu's column with 400 soldiers marched southwest to Chiksia, looking for the Kusukut base. See House, The Japanese Expedition, 115-116.

60. The remains were entombed in an ancient temple in Okinawa in 1898 because those sailors had "died in the service of the state". See G. H. Kerr, Okinawa: The History of an Island People (Boston-Tokyo, 2000), 451-452.

61. Davidson, The Island of Formosa, 147-149.

62. House, The Japanese Expedition, 94.

63. Yübin hōchi shinbun and the Kōbun tsūshi newspapers on their June 15 edition outlined the friendship and the alliance between the two sides. The Japan Daily Herald of 23th June went a step further. Even if the aborigines did not understand flags as national symbols the newspaper implied that they were now under the Japanese protection. For the ultranationalists South Taiwan had now become Tōkyō's protectorate. Eskildsen, "Of Civilization and Savages," 407-410.

64. House attests that fear of Western intervention, protests and even threats crippled and overturned Japanese foreign policy and domestic projects. The lesson was that in the future Japan had to prepare its plans in secrecy in order to avoid foreign opposition. See Ibid., 226. 
morale and discipline declined, requested from Tōkyō a detachment of military police to restore order. However, according to the volunteer in the expedition Adachi Tsunayuki only a small number of men wished to remain in the island. ${ }^{65}$ One of Saigō secondary objectives was the importation and cultivation of foreign plants. For this purpose during these rather dull days he sought to establish a small experimental farm; the plan was abandoned because the proprietors of every suitable area demanded huge compensations for the concession of their land. ${ }^{66}$

The Chinese were informed about the Japanese operation by Wade in April. However, the Yamen reacted only after the 11th of May 1874, when news of the troops' arrival at Amoy reached Beijing. On that day an official protest was sent to Tōkyō stating among others that Soejima during the previous year did not say anything about an armed intervention; in any case Japan ought to have consulted China before acting. Li Hongzhang suggested on 10 May the immediate dispatch of the director of Foochow Arsenal Shen Baozhen (1820-1879) to Taiwan immediately with ships and troops to prevent the Japanese from landing. ${ }^{67}$ His plea was endorsed by the throne despite the critical domestic situation of the Qing empire. ${ }^{68}$ Shen was appointed Special Imperial Commissioner with diplomatic and military powers by the Qing emperor on 14 May. In June Yanagiwara initiated negotiations in Shanghai but they soon came to a deadlock. ${ }^{69}$ In Beijing he met with the Yamen Ministers during August without much success. P'an Wei, the provisional treasurer of Fukien warned the Japanese envoy that 10,000 Qing troops were on their way to Taiwan. ${ }^{70}$ Both sides were immovable from their positions. Yanagiwara was defending his country's legitimate claim to subdue the savages under international law while the Chinese systematically refused to comply with Western law and practices. The Japanese envoy insisted that Beijing had been promptly notified whereas the Ministers asserted their competence and right to manage Taiwan without Japan's assistance. Tension was growing. In the end of July LeGendre departed for South China to enter into negotiations with the Qing Viceroy in Fukien. At Swatow (Shantou) he witnessed in person the Chinese military preparations. Heavy taxes were being levied to the provinces south of Canton to fund the military preparations. In Shanghai and Tianjin, the Chinese were constructing fortifications in case the Japanese attacked ${ }^{71}$ Upon

65. Orbach, "By not stopping," 52.

66. House, The Japanese Expedition, 157.

67. On June 15th and 25th Li advised Shen to depart for Taiwan with 13 and 22 battalions respectively to counter the Japanese provocation. Other Chinese officials in June suggested to the court to approach diplomatically the powers for mediation and a modernization program for the army. Most of them recognized Japan's military superiority. See Mizuno, "Qing China's Reaction," 110-111.

68. At that moment the revolts in Yunnan and Kansu were quelled and another one was breaking out in Sinkiang province. See Leung, "The Quasi-War", 275.

69. LeGendre believed that Yanagiwara's early approach was a mistake. Japan required more time to establish a firm position in Taiwan and then it could dictate its terms. See Gordon, "Japan's Abortive Colonial Venture," 178.

70. A force of 11,500 men was assembled in July but reached Taiwan as late as October. See Ibid., 180.

71. Caruthers, Charles LeGendre, 197-209. 
his arrival at Amoy on August 6 he was arrested by the US marshal stationed at the Amoy consulate in accordance with Bingham's orders but was immediately released. ${ }^{72}$ In the same time the Japanese were also preparing for war: three new steamers were purchased abroad and the garrison in Taiwan grew up to 6,000 men. On 8 July 1874 the cabinet decided not to back down even at the risk of war. Capitulation on this issue would be construed as a sign of weakness on the part of the Meiji government. Prime Minister Sanjo stressed that "the Japanese government has decided to go to war, if [it is] unavoidable" and in the same time an imperial proclamation of war to China was drafted. ${ }^{73}$ The Ministers of the Army and Navy were instructed to devise war plans but Yamagata felt pessimistic about the prospect of an engagement. On the 15th Yanagiwara was ordered to explain to the Qing Ministers that: 1) South Taiwan was "truly unclaimed aboriginal territory" and thus Japan's action righteous, 2) the territory would be colonized for humanitarian reasons, 3) if Beijing desired the land seized by the Japanese, it had to compensate them with around 6 million Mexican silver dollars and guarantee its effective governance. The issues of Korea and Ryūkyū were to be addressed by the Japanese envoy but if China desired to settle these issues with war, Tōkyō would be ready to meet it in the battlefield. On 18 July, Iwakura disclosed that Japan would not withdraw even if China explicitly demanded it. ${ }^{74}$ A limited colonial adventure threatened to escalate into a full-scale war. Soejima, Yanagiwara, Sanjō and the Saigō brothers endorsed the prospect of a war to settle every unresolved issue with Beijing. Vice Admiral Shadwell believed that diplomatic rupture was certain since Japan appeared to be establishing a colony instead of abandoning the island. Furthermore, Minister Wade, anxious to prevent a conflict detrimental to the Far East trade, proposed arbitration to both sides. Both Yanagiwara and the Qing authorities refused his proposal. ${ }^{75}$

On 1 May Ōkubo was appointed High Commisioner and Minister Extraordinary. Since he felt responsible for the launch of the mission he wanted to assume negotiations and resolve personally the critical issue by taking Yanagiwara's place. The orders he received the following day were the same with his predecessor's but he was invested with the power to decide on war if he deemed it unavoidable. He arrived at Beijing on 10 September accompanied by LeGendre and the French legal advisor Boissonade. ${ }^{76}$ His plan was to gain recognition for the expedition's legitimacy and an indemnity, which would uphold Japan's prestige, in exchange for the withdrawal from the aboriginal territories. Li favored this arrangement but war seemed still probable. ${ }^{77}$ During September, Ōkubo conferred with Prince Kung. To Kung's claims he replied

72. Davidson, The Island of Formosa, 159.

73. Gordon, "Japan's Abortive Colonial Venture," 179.

74. Fox, Britain and Japan, 299-300.

75. Ibid., 303.

76. Boissonade appeared skeptical about the legitimacy of Japanese actions in Taiwan: "If one nation takes the action to civilize the barbarians without first inquiring the intention of the neighboring nation that is adjacent to the barbarian territory, the action is considered inappropriate in diplomatic manners and constitutes a mistaken strategy of the nation." See Chang, From Island Frontier to Imperial Colony, 49-50.

77. Mizuno, "Early Meiji Policies," 730-733. 
that the imposition of taxes did not constitute effective control; lack of punitive measures after the aboriginal atrocities against foreign castaways and the Yamen's declarations to Yanagihara in 1873 meant that Japan had not invaded Chinese territory. If aboriginal Taiwan belonged to China why did Beijing fail to punish the savages that had killed foreign sailors? The Chinese side rejected these arguments pointing out that China had its own gradual system of assimilating its subjects and that this was far older than the Western international law. According to them, Japan had bluntly invaded Chinese territory.

Little progress had been achieved and Wade offered his mediation during the negotiations on 26 September. Ōkubo rejected his offer as did the Yamen the day before. On 5 October Ōkubo threatened to leave Beijing as a means to pressure his interlocutors. Five days later however he proposed that Beijing establish a definite boundary between its domain and the aboriginal area. If the Chinese did not reply in 5 days, the negotiations would be terminated. The boundary proposal was eventually rejected. In the meantime, Ōkubo admitted to Wade and the French Minister Francis Henri Louis de Geofroy (1822-1889), that Japan as an exchange for its withdrawal wished only the vindication of its honor and a monetary compensation. On 18 October, the Yamen Ministers promised to govern the savages and "to pay compensation to these Japanese who had suffered at the hands of the aborigines". Consequently Ōkubo demanded 3 million Mexican dollars. Beijing's response was that Japan had only spent 500,000 dollars. The compensation was to be called relief money for the victims' families and it was to be delivered after the withdrawal of Saigō's force. On 23 October the Japanese commissioner departed from Beijing in protest: "Japan has no other way but to proceed with her original plan and annex the territory which she now occupies". ${ }^{78}$

Wade in order to satisfy Ōkubo's wish for a written assurance for payment rushed to the residence of the Qing Grand Secretary to extract a declaration of the exact amount China would offer. Despite Beijing's efforts to secure foreign mediation, believing that it would favour its cause, eventually it was Ōkubo that enjoyed the Russian, British and French Ministers' sympathy. On 25 October the Yamen informed Wade that it was inclined to pay 500,000 taels $(750,000$ mexican dollars), 100,000 for the Ryūkyūan victims and 400,000 as compensation for the buildings and roads the Japanese had built in Taiwan. ${ }^{79}$ In addition Ōkubo demanded an official recognition of Japan's action as righteous. Wade persuaded him to accept half the money in advance and the remaining sum after the evacuation. The dates of the evacuation and of the payment were to be decided later. On 31 October 1874, the Beijing Agreement was signed: Japanese action to "protect its subjects" was deemed legitimate, consolation money was paid to Tōkyō and Beijing promised to keep the aborigines under control. ${ }^{80}$ Previous correspondence and records of this issue were discarded by both countries. On 1 November Ōkubo parted for Taiwan to inform Saigō of the termination of his mission. The British diplomatic

78. Fox, Britain and Japan, 306.

79. P.J. Treat, "Early Sino-Japanese Diplomatic Relations," in Pacific Historical Review, 1, no. 1(Mar., 1932): 22- 23.

80. Leung, "The Quasi-War," 277. 
authorities in both countries were relieved and Bingham was likewise pleased for the peaceful settlement of the dispute. ${ }^{81}$

\section{Conclusion}

In order to secure Saigō's cooperation Ōkubo was accompanied by Higashikuze Michitomi (1834-1912) the grand chamberlain, equipped with an imperial edict ordering the evacuation of the island. Before leaving the island on 3 December the commander-in-chief proclaimed to the aborigines that the land was being ceded to the Chinese government in accordance with its request, and he urged both the friendly and the hostile tribes to obey their new masters. ${ }^{82}$ Saigo and his men were received as heroes in Yokohama amidst festivities by the enthusiastic crowd. On 16 November, Ōkubo and Emperor Meiji asked Parkes to thank Wade for his assistance. ${ }^{83}$ In April 1875, the Department of Aboriginal Affairs that had been created the year before to gather intelligence and handle the issue was abolished. ${ }^{84}$ The expedition, the expense of which was initially estimated at 500,000 yen had cost Japan between 7,700,000 and 9,500,000 yen depending on the source. ${ }^{85}$

The modest but humiliating indemnity obtained from Beijing was not the main prize for the Meiji leaders. Japan by organizing a punitive expedition had acted as an imperial power and got away with it. In addition, the Chinese tacitly accepted Japan's claims on the Ryūkyū Islands and its right to intervene in an area under their nominal control. More importantly Tōkyō, despite its susceptibility to foreign pressures, was able to direct the former samurai's aggressiveness away from home and augment its prestige abroad. Furthermore, Japan projected an image of modernity and civilization that sought to convince the West of its distinctiveness vis-à-vis the backward, decaying, and inferior Far Eastern nations. It was the quest for parity not strategic necessities that drew Japan towards war or the establishment of its first colony. Even if Japan failed to get away with a colony in 1873 its early expansionistic tendencies and its quest for prestige were made apparent right from the start. Western press praised and acknowledged Japan's "generosity" in surrendering Taiwan back to China and for acting chivalrously for the sake of the whole civilized world. For instance, on 6 December 1874 the New York Times suggested about the matter

81. Caruthers, "Filibustering to Formosa," 452.

82. Caruthers, Charles LeGendre, 241.

83. Ōkubo in February 1875 mentioned to the emperor the benefits of his successful mission: the status of Ryūkyū was clarified, the abuses to the imperial subjects were vindicated, security in those waters was consolidated and Japan's influence was augmented. To these exploits he added the "early recognition by the foreigners that Japan was capable of preserving law and order". Thus a step towards the revision of the unequal treaties was achieved. LeGendre observed that the campaign provided the armed forces with valuable experience. The Qing governor of Foochow was also delighted in a perverse way. He told Wade that the fact that the Japanese lost 800 men due to illnesses was gratifying. However, not everyone was content. The Japanese Navy Minister and Councilor Kido Takayoshi resigned in April 1874 in protest to the government's reckless Taiwan policy. See Fox, Britain and Japan, 309-310.

84. House, The Japanese Expedition, 223.

85. Kim, The Last Phase of the East Asian World Order, 199. 
that: "Japan proved itself the honorable and generous nation we now know it to be"; Japan was "...the youngest member of the family of civilized nations...". 86 That was exactly what Meiji leaders longed for.

A positive consequence for China was the eventual recognition of its sovereignty in Taiwan by the foreign powers. At the same time however, Beijing's slow reflexes and military unpreparedness have been clearly demonstrated. Furthermore, Japan's adoption of western practices to resolve the issue eradicated Li Hongzhang's hopes for an Asian alliance to cope with the Western threat. ${ }^{87}$ During the first months of 1875 , the Chinese made some vigorous attempts to assume authority over the savages of the interior. In January however, two Chinese were murdered in an aboriginal village in south Taiwan. Beijing after witnessing Japan's comfortable subjugation of the savages dispatched 500 men to Sai-tao to retaliate. Half of them fell victims to the natives' guerrilla tactics. ${ }^{88}$ Under Qing rule the island lacked social order and firm administration. Immigrants from mainland China and the aborigines were in a constant conflict as the Chinese were penetrating the interior to secure arable land and exploit the island's natural resources. The aborigines' determination to protect their ancestral homes signified a vicious cycle of mutual vendettas, atrocities and warfare. Several dozen official expeditions were organized against the "raw savages" between 1875 and $1895 .{ }^{89} 159$ sizeable rebellions took place during the period of nominal rule by the Qing. Beijing after almost losing the island in 1874 came to revaluate its strategic position. Thus, Taiwan's development and pacification was seen for the first time as an essential part of the Qing broader policy of "self-strengthening". Shen Baozhen, the orchestrator of the island's defence against Saigō's forces, was the first of a series of Qing governors that sought to erect fortifications, build roads and consolidate Qing rule in Taiwan to prevent further discretions. As a result of another external threat, the French occupation of Keelung and Tan-shui during the Sino-French conflict of 1884-1885, Taiwan was proclaimed a Qing province; previously Taiwan and the Pescadores comprised a prefecture under the jurisdiction of the provincial government of Fukien. ${ }^{90}$

86. A British reporter sarcastically pointed out that the Japanese some years ago used to murder shipwrecked seamen. Beheading and conquering a feeble barbarian tribe in Taiwan did not automatically mean that Japan was an equal partner of the civilized nations. See Caruthers, "Filibustering to Formosa," 453.

87. Ibid., 455-454.

88. Caruthers, Charles LeGendre, 168-169.

89. R. Gardella, "From Treaty Ports to Provincial Status, 1860-1894," in Taiwan: A New History, ed. M. A. Rubinstein (New York-London, 2007), 180-181.

90. Ibid., 188-191. 


\section{Bibliography}

Caruthers, S. Charles LeGendre, American Diplomacy, and Expansionism in Meiji Japan, 1868-1893. PhD Dissertation, University of Colorado, 1966.

Caruthers, S. "Filibustering to Formosa: General Charles LeGendre and the Japanese." In Pacific Historical Review, Vol. 40, No. 4, November 1971, pp. 442-456.

Chang, L.-C. From Island Frontier to Imperial Colony: Qing and Japanese Sovereignty Debates and Territorial Projects in Taiwan, 1874-1906. $\mathrm{PhD}$ Dissertation, Harvard University, 2003.

Davidson, W.J. The Island of Formosa, Past and Present: history, people, resources, and commercial prospects: tea, camphor, sugar, gold, coal, sulphur, economical plants, and other productions. London-New York, 1903.

Eskildsen, R. "Of Civilization and Savages: The Mimetic Imperialism of Japan's 1874 Expedition to Taiwan." In The American Historical Review, 107, no. 2 (April 2002): 388-418.

Fox, G. Britain and Japan, 1858-1883. London, 1969.

Fraleigh, M. "Japan's First War Reporter: Kishida Ginkō and the Taiwan Expedition." In Japanese Studies, 30, no. 1(May 2010): 43-66.

Gardella, R. "From Treaty Ports to Provincial Status, 1860-1894." In Taiwan: A New History, edited by M. A. Rubinstein, 163-200. New York-London, 2007.

Gordon, L. "Japan's Abortive Colonial Venture in Taiwan, 1874." In The Journal of Modern History, Vol. 37, No. 2, June, 1965, pp. 171-185.

Gordon, L. "The Cession of Taiwan: A Second Look." In Pacific Historical Review, 45, no. 4 (November 1976): 539-567.

House, H. E. The Japanese Expedition to Formosa. Tokyo, 1875.

Kerr, H. G. Okinawa: The History of an Island People. Boston-Tokyo, 2000.

Kim, K.-H. The Last Phase of the East Asian World Order: Korea, Japan, and the Chinese Empire, 1860-1882. London, 1980.

Lebra, C.J. Ōkuma Shigenobu: Statesman of Meiji Japan. Canberra, 1973.

McWilliams, C. W. "East Meets East. The Soejima Mission to China, 1873." In Monumenta Nipponica, 30, no. 3(Autumn, 1975): 237-275.

Mizuno, N."Early Meiji Policies towards the Ryukyus and the Taiwanese Aboriginal Territories." In Modern Asian Studies, 43 no. 3(May, 2009): 683-739.

Mizuno, N. "Qing China's Reaction to the 1874 Japanese Expedition to the Taiwanese Aboriginal Territories." In Sino-Japanese Studies, 16(2009): 100-125.

Munsterhjelm, M. "Corporate Protectors of State Sovereignty: Mitsubishi's and a Taiwan Affiliate's Accounts of Relations with Taiwan Aborigines." In Asian Ethnicity, 15, no. 3 (2014): 351-373.

Orbach, D. "'By not stopping': The first Taiwan expedition (1874) and the Roots of Japanese Military Disobedience." In The Journal of Japanese Studies, 42, no. 1(Winter 2016): 29-55.

Pak-Wah, L. E. "The Quasi-War in East Asia: Japan's Expedition to Taiwan and the Ryūkyū Controversy." In Modern Asian Studies, 17 no. 2(1983): 257-281.

Suzuki, S. Civilization and Empire: China and Japan's Encounter with European International Society. New York, 2009.

Treat, J. P. "Early Sino-Japanese Diplomatic Relations." In Pacific Historical Review, 1 no. 1(March, 1932): 18-35.

Uemura, H. "The colonial annexation of Okinawa and the logic of international law: the formation of an 'indigenous people' in East Asia." In Japanese Studies, 23, no. 2(September 2003): 107-124.

Yamamura, K. "The Founding of Mitsubishi: A Case Study of Japanese Business History." In The Economic Development of Modern Japan, 1868-1945: From the 
Meiji Restoration to the Second World War, vol. 1, edited by S. Toliday, 343-362. Cheltenham, 2001. 
